Studia i Materiały, 2/2018 (29), cz. 2: 41-46

\title{
Changes of Venture Capital Financing in the USA and in Europe
}

\author{
Elżbieta Pohulak-Żotędowska*
}

\begin{abstract}
In this article, the author discusses the problem of financing innovation, especially disruptive (or breakthrough) innovation. This type of innovation has some special features that make it different from incremental innovation. First of all, disruptive innovations are the ones that have great growth-creating potential. They are new products or services that replace the existing ones. They break the present production cycle, cause risk and uncertainty, and provoke entrepreneurs' risk-averse behavior. Because if profits motivate entrepreneurship, uncertainty demotivates it. High uncertainty, high capital intensity and high profit prospects make investing in this sort of innovation a potentially interesting issue.

There is a common perception that venture capital $(V C)$ has become an intermediary in financial markets, providing capital to firms that might otherwise have difficulty attracting financing. As these firms are thought to be small, young and innovative, plagued by the "liability of newness", venture capital is expected to fulfill an important role in the economy - it is meant to be a tool of financing novel and risky ventures and, hence, it is a driver of technological and economic progress.

The goal of the article is an attempt to answer the question if venture capital is risk-loving or risk-averse capital. The methods used include a critical analysis of literature and data analysis. The goal of the article is to show the role VC plays in financing Europe's innovations, and to answer the question if $V C$ is risk-loving capital.
\end{abstract}

Keywords: innovation, risk, uncertainty, venture capital.

Submitted: 09.03.18 | Accepted: 04.07.18

\section{Zmiany w finansowaniu kapitałem venture w USA i Europie}

Niniejszy artykut stanowi próbę ukazania problemów finansowania działalności innowacyjnej młodych przedsiębiorstw. Ze szczególna uwaga autorka podchodzi do innowacji przetomowych. Istotna cecha innowacji przełomowych jest fakt, że tworza nowe rynki, sa to innowacje przerywajace dotychczasowy tok rozwojowy. A z punktu widzenia tworzenia innowacji $w$ dziedzinach wymagajacych nowej wiedzy jest to cecha pożadana. Jednakże druga cecha charakterystyczna jest fakt, że pojawienie się innowacji przetomowej poczatkowo powoduje pogarszanie się funkcjonalności produktów. Innowacje przetomowe przerywaja istniejacy proces produkcyjny. W takim kontekście dziatalnośc innowacyjna jest działalnościa obarczona wysokim ryzykiem i niepewnościa. Cechy te moga powodować u przedsiębiorców awersję do ryzyka. Wysoki poziom niepewności, kapitałochłonność, lecz również i perspektywa wysokich zysków sprawiaja, że inwestowanie $w$ działalność innowacyjna jest potencjalnie interesujaca

\footnotetext{
* Elżbieta Pohulak-Żołędowska - PhD, Management and Tourism Economics and Economic Policy Dept., Faculty of Economics, Wrocław University of Economics. https://orcid.org/0000-0002-8267-3705. Correspondence address: Wrocław University of Economics, Nowowiejska 3, 58-500 Jelenia Góra; e-mail: elzbieta.pohulak-zoledowska@ue.wroc.pl.
} 
dla inwestorów. Uważa się, że kapitat venture stat się instytucja pośredniczaca na rynku kapitału, zapewniajaca doptyw funduszy do ryzykownych, innowacyjnych przedsięwzięć, które bez kapitatu ryzyka nie będa miaty szansy na wejście na rynek. Celem niniejszego opracowania jest próba pokazania różnic w podejściu do finansowania innowacji kapitałem ryzyka $w$ Stanach Zjednoczonych i Europie.

Słowa kluczowe: kapitał ryzyka, innowacje przełomowe, finansowanie, gospodarki wiedzy.

Nadesłany: 09.03.18 | Zaakceptowany do druku: 04.07.18

JEL: D81, E22, G24, O33

\section{Introduction}

According to Schumpeter's idea of creative destruction, innovation is based upon a new order, very often set on ruins of past one. A new idea can be the starting point of a new enterprise (a start-up). It can also be a reason for the bankruptcy of an enterprise that has not met market needs. One must notice that the innovation process is highly uncertain, and its uncertainty is driven by risk. Innovation (fresh) outcomes are often new to the market, and they are not market blockbusters with skyrocketing sales, but rather smart, strongly undercapitalized start-ups. This state of affairs causes future uncertainty and risk of loss. Innovation can create growth and wealth. But - as a so far unknown, fresh solution to a problem (often undefined one) - also brings risk. Such risk must be taken to create, at first, value for a risk-loving entrepreneur and, after that, to create economic growth In knowledge economy conditions, innovation is more and more often created inside scientific laboratories and is a result of a laboratory's R\&D activity. High costs of research discourage investors from investing in innovation activity.

Schumpeter's notion of creative destruction shows that capital markets find the most promising projects. But is it really so? Literature focuses on issues connected with implementation and commercialization of promising ideas, but if capital markets are a good solution for financing innovation, why does the early stage of innovation suffer a lack of capital?

\section{VC in Financing Innovation}

Venture capital funding has long been a source of financing for entrepreneurs, breakthrough technologies, and start-ups.
Venture capital supports companies, ideas, and products that carry significant risks and therefore may have difficulty securing more traditional sources of capital support. Many innovative products and services that are supported by venture capital funding have very long development cycles (time an innovative idea needs to be transferred into a product and to get to the market) and are not appealing to investors seeking quicker returns on their investment. Venture capital funding is responsible for financing many innovations in information technology, biotechnology, life sciences, and health care. Venture capital firms seek out radically innovative ideas (also called disruptive technologies). One of the areas where venture capital funding has enabled the development of many digital-era tools and applications is IT. But it is healthcare and life sciences that remain a favorite area of VC funding and the value of venture capital financing is well documented by social and economic benefits that have come about through venture capital backing. ${ }^{1}$

This category of investment known as "risk" or "venture capital" is investment in companies by specialized venture capital firms. It is a part of "private equity", that is equity investment in companies not listed on a stock market, as opposed to equity investment in publicly traded companies. Venture capital firms act as principals managing the funds of individuals, institutions and their own money. There are six main financing stages in the venture capital process, related to the stages of development of venture-backed companies:

- The "early stage" is the financing before a venture initiates commercial manufacturing and sales, and before it generates profit. This includes "seed" and "start-up" financing, the former provided to 
research, evaluate and develop an initial concept, and the latter to support product development and initial marketing.

- "Expansion" - financing supports growth and expansion of a company's manufacturing and sales capacity in order to generate profits.

- "Replacement" involves the sale of a portion of the existing shares to other venture capital companies or to other shareholders.

- "Management buyout" is financing provided to enable current operating management and investors to acquire the whole company, a product line or business. "Management buy in" is financing provided to outside managers to buy the company.

- "Exit" is the final stage, achieved either through an initial public offering of the shares in a primary stock market or through an arranged sale to a financial or strategic buyer of the company.

The most restrictive definition of venture capital excludes management buyouts and buy-ins, while a more expansive conception includes both. In Europe, the extended definition is preferred while the more restrictive one is widely used in the United States. In the US market, the range of activities encompassed by the extended definition is referred to as "private equity".

\section{VC in Enterprises}

In the majority of countries for which data is available, venture capital investments represent a very small percentage of
GDP, which is often less than $0.03 \%$ (Figure 1). Exceptions are Israel and the United States, where the venture capital industry is more mature and represents $0.5 \%$ and $0.2 \%$ of GDP respectively (OECD, 2013).

There is no other as transparent production factor as capital (here - financial capital). It completes the economy's architecture (beside the physical capital). Its ability to foster growth is widely used by enterprises. The specificity of venture capital seems to bring an interesting notion about its geographical distribution. Despite capital's transparency, the venture capital distribution in uneven. Companies based in the USA receive around $2 / 3$ of venture capital funds invested globally. European firms take the second place in terms of venture capital investments, and they receive around $15 \%$ of global venture capital backing (Nepelski et al., 2016). The reason for this inequality is being widely discussed in the literature, with accents put on the small business ethos in the USA, stock development and characteristics in both regions and so on (de la Dehesa, 2002).

The story of venture capital involvement in young, high-potential enterprises' development is a short one. It started in the 90's during the dot.com burst and venture capital hit the top profits in that period. In the mid-90's, there were only around 100 European companies that were backed by this sort of funds. In 2000, this number increased to over 3,200 companies that received 19 billion euros from venture capital funds. However, after the dot. com burst, the activity of venture capital in Europe decreased considerably and has

Figure 1. Venture capital investment as a percentage of GDP (US dollars), 2012

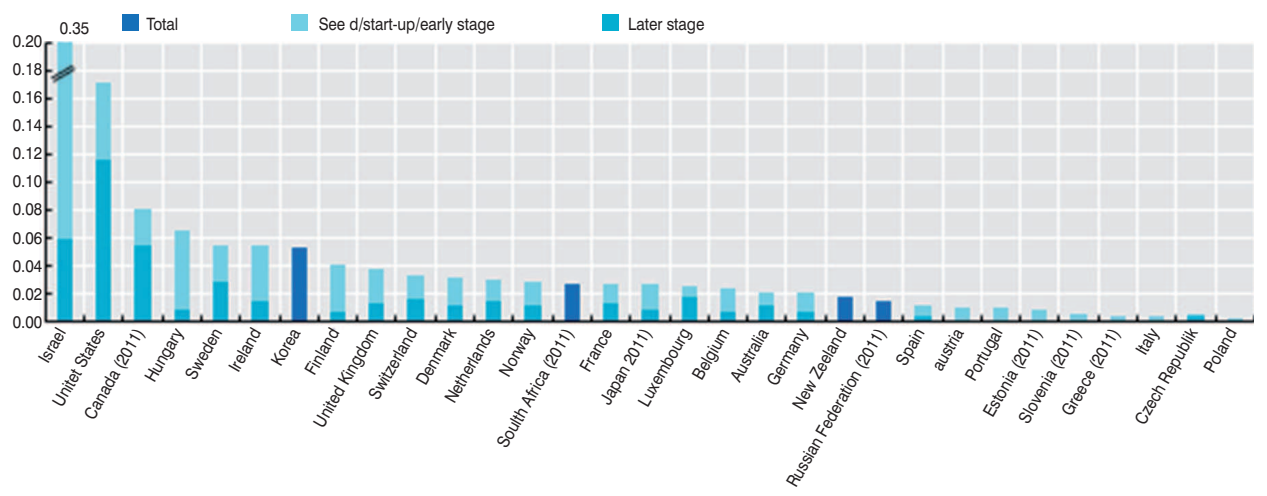

Source: OECD, 2013.

Wydział Zarządzania UW https://doi.org/10.7172/1733-9758.2018.29.4 
Figure 2. Global annual amount raised by VC-backed companies by world regions

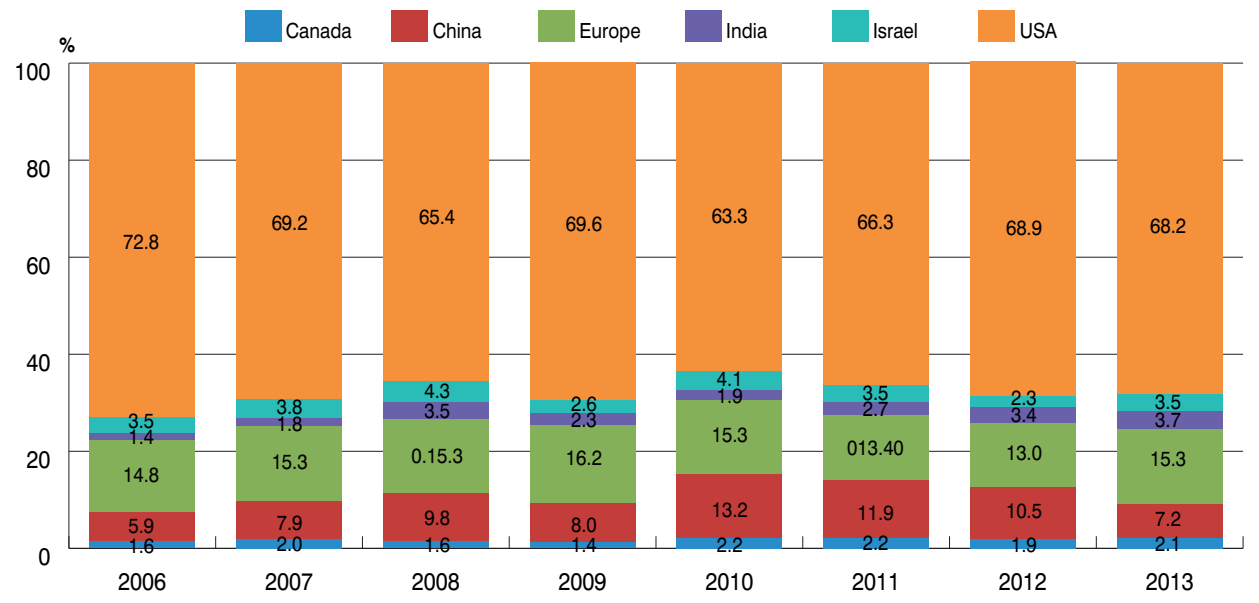

Source: Nepelski (2016).

never regained its top levels. Between 2002 and 2014, European companies received on average EUR 4.4 billion annually. In 2014, this quota increased to 5.8 billion euros (Nepelski, 2016). The countries with the highest shares of European companies backed by venture capital are: the United Kingdom, Germany and France. For example, companies from the United Kingdom represent nearly one quarter of all European venture-capital-supported companies. In the period 1995-2014, these companies also received one third of all venture capital funds invested in Europe. The top ten European countries constitute $90 \%$ of the total number of VC-backed companies and the total amount raised in Europe between 1995 and 2014 (Nepelski, 2016).

Also the age structure of enterprises backed by venture capital has changed. Venture capital funds in Europe have moved from seed to later stage financing during the period of their existence (Nepelski, 2016). In 1995, $7 \%$ of all VC funds were allocated to seed, and only $10 \%$ to later stage financing. Two decades later, $0.5 \%$ of all venture capital funds were allocated to seed and $56 \%$ to later stage financing. Companies from the IT industry dominated the venture capital companies in Europe twenty years ago. In the 2010-2014 period, $44 \%$ of VC-backed firms in Europe belonged to the business, consumer and retail industry and $26 \%$ to the IT sector. The healthcare industry raises the highest levels of VC financing. The business, consumer and retail and the IT industry raises a median of around EUR 1.5 million per company (Nepelski \& De Prato, 2014).

The employment of up to 100 employees is typical for $92 \%$ of all venture-capitalsupported companies based in Europe. Only $1 \%$ of the European companies that received venture capital in the last 20 years have 450 or more employees. The size of VC-backed companies is decreasing, while their age is increasing. While the median size of a company that received venture capital backup in the later financing stage in the period 1995-1999 was 74 employees, in 2010-2014 this number dropped to 35 employees. Nearly $90 \%$ of all VC-backed companies based in Europe are up to 8 years old. In general, the age of VC-backed companies has increased over the last twenty years.

According to a detailed study of VC-supported companies in Europe, besides a very small number of VC-backed companies in Europe, one can observe extreme geographical concentration of VC activity (Nepelski et al., 2016). For example - companies located in the UK represent nearly one quarter of all European venture-capital-supported companies and one third of all venture capital money invested in Europe. To compare - the UK accounts for only $17 \%$ of the EU-28 GDP. This pattern of geographic concentration continues at the country level. In 2014, the European start-up hotspots, i.e. the top 20 European 
cities by the number of VC-backed companies, accounted for $58 \%$ of all European VC-backed companies and $69 \%$ of all the money received by those companies (Nepelski et al., 2016). Paris, London and Berlin lead this ranking.

The geographical concentration of startups does not come as a surprise. It is a predictable result of agglomeration, a process widely described in economic literature and also observable in the US (Silicon Valley, North Carolina knowledge triangle, Boston route 128) and elsewhere (Bangalore in India or Changzhou in China). Factors such as the spatial proximity of similar and related firms and industries and the general tendency of people and economic activity to locate in large cities and economic core regions all lead to agglomeration. The agglomeration of $\mathrm{R} \& \mathrm{D}$, innovation and business activity facilitates local knowledge spillovers and fosters the local business system (Nepelski \& De Prato, 2014).

The location of a start-up does not only matter for the probability of receiving VC funding, but also for its volume and continuity. Start-ups based in major European start-up hotspots have higher chances to both receive more $\mathrm{VC}$ money and to be backed by VC more frequently, as compared to an average European VC-backed start-up. The median amount raised by a VC-backed company in Europe was EUR 1.5 million. In contrast, the same value for a company based in the European hotspots was close to EUR 2 million.

As the continuity of VC funding is highly indicative of the growth potential of firms (Gompers \& Lerner, 2001; Lerner, 1999), it is interesting to know if start-ups based in the European hotspots exhibit also higher growth potential, as compared to firms created in other parts of Europe. This raises a question of whether European start-ups migrate to the venture capital hotspots in order to improve their funding prospects.

\section{Conclusion}

Looking at the patterns of venture capital activity in terms of funding stage and the profile of companies receiving this sort of capital support leads to some interesting observations. Over the last two decades, venture capital funds have moved away from seed to a later stage of funding and from young to older companies. For exam- ple, in $1995,7 \%$ of all venture capital funds were allocated to seed, and only $10 \%$ to a later stage. Two decades later, $56 \%$ of all venture capital financing went to a later and only $0.5 \%$ to the seed stage. Also the characteristics of VC-backed companies have changed over the last twenty years. In particular, the age of European companies supported by venture capital increased. Today, around $90 \%$ of those companies are up to 8 years old and have up to 100 employees. This is likely to be related to an increasing focus of venture capital funds on a later stage rather than on seed.

In conclusion, the overview of venture capital activity in Europe shows that it is extremely scarce, geographically concentrated and has become increasingly more risk-averse. Venture capital funds have focused on mature companies with established technologies and market presence and established in certain locations. This challenges the image of VC funds as providers of financing to young, innovative and high-risk enterprises and raises a question of the position of venture capital funds in the process of financing innovation in general and innovative ventures without previous commercial record in particular. In other words, a large share of European companies, even extremely innovative ones, needs to rely on sources other than VC funds to finance their innovative activity. This raises the issue of other sources of innovation financing, including the public sector. The latter one is said to have an important role in supporting early-stage innovative activity by small firms given the tenuous nature of the venture capital cycle at this preliminary, yet critical, stage of firm activity.

\section{Endnotes}

1 "Venture Capital \& the Finance of Innovation" Research Starters eNotes.com, Inc. eNotes.com 13 Aug, 2017 http://www.enotes. com/research-starters/venture-capital-financeinnovation\# research-starter-research-starter.

\section{References}

Aghion, P., \& Tirole, J. (1994). The management of innovation. Quarterly Journal of Economics, 109(4), 1185-1209. http://doi.org/10.2307/2118360.

Akcigit, U., \& Kerr, W.R. (2012). Growth through heterogeneous innovations. NBER Working Paper No. 16443. http://doi.org/10.2139/ssrn.2096240. 
Altshuller, G.S. (2007). The innovation algorithm: TRIZ, systematic innovation and technical creativity. Worcester, Mass. Technical Innovation Center. Retrieved from: http://www.evolocus.com/Textbooks/Altshuller2007.pdf.

de la Dehesa, GG. (2002). Venture capital in the United States and Europe. Occasional Papers, 65 Washington, DC: Group of Thirty. Retrieved from http://group30.org/images/uploads/publications/ G30_VentureCapitalUSEurope.pdf.

Gompers, P.A., \& Lerner, J. (2002). The money of invention. How venture capital creates new wealth. Boston: Harvard Business School Press. http://doi. org/10.1145/504689.763904

Grossman, S.J., \& Hart, O.D. (1986). The costs and benefits of ownership: A theory of vertical and lateral integration. Journal of Political Economy, 94 691-719. http://doi.org/10.1086/261404.

Hall, B., \& Lerner, J. (2010). The financing of $R \& D$ and innovation. In B. Hall \& N. Rosenberg (Eds.), Handbook of the economics of innovation (pp. 609-639) Netherlands: Elsevier. http://doi. org/10.1016/S0169-7218(10)01014-2.

Hall, B.H., Griliches, Z., \&. Hausman, J.A. (1986) Patents and R\&D: Is there a lag?. International Economic Review, 27(2), 265-283. http://doi. org/10.2307/2526504.

Hart, O., \& Moore, J. (1990). Property rights and the nature of the firm. Journal of Political Economy, 98, 1119-1158. http://doi.org/10.1086/261729.

Holmstrom, B. (1989). Agency costs and innovation. Journal of Economic Behavior \& Organization, 12(3), 305-327. http://doi.org/10.1016/01672681(89)90025-5.

Kerr, W. R., \& Nanda, R. (2014). Financing innovation (Harvard Business School Entrepreneurial Management Working Paper No. 15-034). Retrieved from: http://doi.org/10.2139/ssrn.2519572.

Kerr, W.R., Nanda, R., \& Rhodes-Kropf, M. (2014). Entrepreneurship as experimentation. Journal of Economic Perspectives, 28(3), 25-48. http:// doi.org/10.1257/jep.28.3.25.

Knight, F.H. (1921). Risk, uncertainty, and profit. Boston, MA: Houghton Mifflin. http://doi.org/ 10.1017/CBO9780511817410.005.
Lerner, J. (1999). The government as venture capitalist: The long-run impact of the SBIR program. The Journal of Business, 72(3), 285-318. http://doi. org/10.1086/209616.

Levin, E. (2016). Why Europe lags behind the US in $V C$ investment. Retrieved from: https://venturebeat com/2016/03/13/why-europe-lags-behind-the-us-invc-investment/ (25 . 05.2017).

Nepelski, D. (2016). The role of venture capital in financing innovation in Europe. Retrieved from: https://www.ispim-innovation.com/singlepost/2016/09/01/Daniel-Nepelski-The-role-of-Venture-Capital-in-financing-innovation-in-Europe (5.05.2017).

Nepelski, D., \& De Prato, G. (2014). Key findings and implications of the European ICT Poles of Excellence project. Seville: JRC-IPTS.

Nepelski, D., Piroli, G., \& De Prato, G. (2016) European start-up hotspots: Analysis of venture capital financing in Europe. JRC Scientific and Policy Reports, EUR 28021 EN. Joint Research Centre. http://doi.org/10.2791/39207.

Nord, W.R., \& Tucker, S. (1987). Implementing routine and radical innovations. Lexington: Lexington Books.

OECD. (2013). Access to finance: Venture capital. In Entrepreneurship at a glance 2013. Paris: OECD Publishing. http://doi.org/10.1787/entrepreneur_ aag-2013-27-en.

Scherer, F.M., \& Harhoff, D. (2000). Technology policy for a world of skew-distributed outcomes. Research Policy, 29(4-5), 559-566. http://doi. org/10.1016/S0048-7333(99)00089-X.

Schumpeter, J.A. (1934). The theory of economic development. Cambridge, MA: Harvard University Press. http://doi.org/10.1007/0-306-48082-4_3.

Van de Ven, A.H. (1986). Central problems in the management of innovation. Management Science, 32(5), 590-607. http://doi.org/10.1287 mnsc.32.5.590.

Venture capital \& the finance of innovation, research starters, eNotes.com, Inc. eNotes.com 13 August 2017. Retrieved from http://www.enotes. com/research-starters/venture-capital-finance-inno vation\# research-starter-research-starter. 